\title{
Utility of P-SEP, sTREM-1 and suPAR as Novel Sepsis Biomarkers in SARS-CoV-2 Infection
}

\author{
Sagar Dholariya ${ }^{1} \cdot$ Deepak N. Parchwani $^{1}$ (D) Ragini Singh $^{1} \cdot$ Madhuri Radadiya $^{2}$. \\ C. D. S. Katoch ${ }^{1}$
}

Received: 15 April 2021 / Accepted: 18 September 2021/Published online: 6 October 2021

(C) The Author(s), under exclusive licence to Association of Clinical Biochemists of India 2021

\begin{abstract}
The coronavirus disease 2019 is a highly contagious viral infection caused by SARS-CoV-2 virus, member of coronaviridae family. It causes life threatening complications due to complexity and rapid onset course of the disease. Early identification of high-risk patients who require close monitoring and aggressive treatment remains challengeable till date. Novel biomarkers which help to identify high risk patients at the early stage is high priority. Objective of this review to find utility of P-SEP, sTREM-1 and suPAR for diagnosis, risk stratification and prognosis of SARS-CoV-2 infected cases. Soluble receptors like, P-SEP, STREM-1 and suPAR have been involved in immune regulation in SARS-CoV-2 infection and elevate more in severe cases. A comprehensive research of databases like PubMed, EMBASE, CNKI and Web of Science was performed for relevant studies. A total of nine out of fifteen research literature in initial screening were included for this review. Interestingly all studies have reported high levels of P-SEP, sTREM-1 and suPAR in SARS-CoV-2 infected cases and the biomarkers positively correlated with severity of infection. This implies that P-SEP, sTREM-1 and suPAR can be implemented as surrogate marker in blood profile for early diagnosis, risk stratification and prognosis in SARS-CoV-2 for better management in Indian population at the current situation.
\end{abstract}

Keywords SARS-CoV-2 - Biomarkers - Sepsis · P-SEP . STREM-1 $\cdot$ suPAR

Deepak N. Parchwani

drdeepakparchwani@yahoo.com

1 All India Institute of Medical Sciences, Rajkot, Gujarat, India

2 PDU Medical College, Rajkot, Gujarat, India

\author{
Abbreviations \\ ACE2 Angiotensin-converting enzyme 2 \\ Covid-2019 Coronavirus disease 2019 \\ DIC Disseminated intravascular coagulation \\ ORF Open reading frame \\ SARS-CoV-2 Severe acute respiratory syndrome \\ coronavirus-2 \\ sTREM-1 Soluble triggering receptor expressed on \\ myeloid cells \\ suPAR Soluble Urokinase-type plasminogen \\ activator receptor \\ TMPRSS2 Transmembrane protease, serine 2
}

\section{Introduction}

Coronavirus disease (COVID-19) has emerged as an infectious disease caused by novel member of coronavirus family, Severe Acute Respiratory Syndrome Coronavirus2 (SARS-CoV-2). China reported first case of COVID-19 as pneumonia of unknown origin in December 2019 at Wuhan city. Then it spread immensely all over the world with high contagious rate [1]. WHO declared it as public health emergency of international concern on 30 January, 2020 [2] and as a global pandemic on 11 March, 2020 [3]. As per WHO statistics, the total number of cases reached to $176,156,662$ and almost 3,815,486 deaths as on 14 June, 2021, spreading continuously with high infectivity till date. Animal to human transmission (Bat $\rightarrow$ Pangolin $\rightarrow$ Human) was considered as main transmission route as first case had reported direct exposure with the sea market. Human to human transmission occurs mainly through 
respiratory droplets or aerosols formed during talking, sneezing and coughing of the infected individuals $[4,5]$.

SARS-CoV-2 has greater affinity for ACE2 receptor for entry into cells compared to SARS virus of year 2003 suggesting its higher contagious characteristics. Patients presenting with underlying medical comorbidities, like, diabetes, cardiovascular diseases, chronic respiratory diseases and cancers and age more than 70 years have reported high hospital admission and mortality rate [6, 7]. Clinical presentation of SARS-CoV-2 is very complex and variable. Most common presenting symptoms are fever, cough, myalgia, breathlessness, headache, sore throat, gastrointestinal symptoms and loss of smell/taste [8]. But it may also present as complex multisystem inflammatory syndrome due to combination of inflammation and specific host defence mechanism [9]. Hence, it is an essential to be acquainted with the molecular mechanism of virus on human cells which may further help to identify novel biomarkers for screening and prognosis of SARS-CoV-2.

SARS-CoV-2 is enveloped virus with positive sense, single stranded RNA, genomic size of $26-32 \mathrm{~kb}$, from the family of $\beta$-coronaviridae [10]. It composed of four structural proteins, Spike protein (S), Enveloped Protein (E), Nucleocapsid protein $(\mathrm{N})$ and Membrane protein $(\mathrm{M})$. $S$ protein protrudes from virus surface and consists of two subunits, S1 and S2. S1 helps the virus to binds with ACE2 receptor on host cells through its receptor binding domain and S2 takes part in fusion of viral and host cell membrane $[11,12]$. After attachment of S protein with ACE2 receptor, $S$ protein becomes active through two step protease cleavage process. First cleavage occurs at $S_{1} / S_{2}$ cleavage site for priming which stabilize the S2 subunit. Second cleavage occurs at the site near to fusion peptide in the $S_{2}$ subunit which activates the $S$ protein and leads to conformation changes and fusion of viral with host cell membrane [13, 14]. After fusion, virus enters into host cells and releases its genetic material inside the cells. RNA polymerase synthesizes new negative sense RNA from available positive sense RNA. This negative sense RNA synthesizes positive sense RNA which further produces new proteins in the cytoplasm. $\mathrm{N}$ protein attaches with newly synthesized RNA and M protein assists in incorporation to endoplasmic reticulum. Newly synthesized nucleocapsids enfold into ER and then transfers to cell membrane via ER lumen and golgi vesicle, from where it transfers to extracellular space by exocytosis. The newly synthesized virions attack adjacent cells and spread the infection $[15,16]$.
Stages and Pathophysiology of SARS-CoV-2

\begin{tabular}{|c|c|}
\hline Stage & Pathophysiology \\
\hline Asymptomatic phase & $\begin{array}{l}\text { In this stage, SARS-CoV-2 virus binds to } \\
\text { the highly expressed ACE2 receptor in the } \\
\text { nasal epithelial cells. Limited replication } \\
\text { of virus for initial couple of days causes } \\
\text { local spreading of infection with } \\
\text { inadequate immune response. Despite } \\
\text { having a low viral load, patients are very } \\
\text { contagious throughout this phase [17] }\end{array}$ \\
\hline $\begin{array}{l}\text { Invasion into upper } \\
\text { respiratory tract }\end{array}$ & $\begin{array}{l}\text { During this stage, the virus spreads to the } \\
\text { upper respiratory tract. Cells infected with } \\
\text { virus releases interferons and XXCL-10 in } \\
\text { the presence of greater immune response. } \\
\text { Infection will not spread to advanced } \\
\text { stage if individual has enough immune } \\
\text { response [18] }\end{array}$ \\
\hline $\begin{array}{l}\text { Invasion into lower } \\
\text { respiratory tract }\end{array}$ & $\begin{array}{l}\text { In this stage virus invades the type } 2 \\
\text { pneumocytes and further replication } \\
\text { produces more nucleocapsids. } \\
\text { Pneumocytes release of more cytokines } \\
\text { like, interleukins, TNF- } \alpha \text {, macrophage } \\
\text { inflammatory protein-1 } \alpha \text { (MIP-1 } \alpha \text { ), } \\
\text { monocyte chemoattractant protein-1 } \\
\text { (MCP-1) and CXCL-10, leads to cytokine } \\
\text { storm. Attraction and sequestration of } \\
\text { CD4 and CD } 8 \text { cells along with persistent } \\
\text { inflammation and viral replication } \\
\text { damages pneumocytes } 1 \text { and } 2 \text {, results in } \\
\text { diffuse alveolar damage and acute } \\
\text { respiratory distress syndrome [19] }\end{array}$ \\
\hline $\begin{array}{l}\text { Multi-organ } \\
\text { involvement }\end{array}$ & $\begin{array}{l}\text { ACE2 receptors are widely expressed in } \\
\text { various organs such as lungs, heart, colon, } \\
\text { blood vessels, kidney and liver. This } \\
\text { extensive distribution of receptor } \\
\text { aggravates multi organ injury and } \\
\text { systemic failure. Orf1ab, ORF3a and } \\
\text { ORF10 proteins of SARS-CoV-2 attacks } \\
\beta 1 \text { chain of hemoglobin, while spike } \\
\text { protein and ORF10 have binding affinity } \\
\text { to porphyrin. This reduces oxygen and } \\
\text { carbon dioxide carrying capacity of } \\
\text { hemoglobin. Furthet, activation of } \\
\text { coagulation cascade in presence of } \\
\text { cytokine storm produces systemic } \\
\text { vasculitis which further leads to sepsis and } \\
\text { DIC [20]. Delayed in diagnosis and } \\
\text { treatment results in involvement of } \\
\text { various organs [21] }\end{array}$ \\
\hline
\end{tabular}

SARS-CoV-2 causes severe and deadly complication like, sepsis, if there is delayed diagnosis and treatment. There is requirement to identify new and effective biomarkers for risk stratification of SARS-CoV-2 cases. Dysregulated 
immune reaction in presence of infection causes ominous organ dysfunction which is called sepsis [22]. Sepsis is common complication of SARS-CoV-2 which requires long time hospital stay and ICU admission [23]. Sepsis further induces host immune response and releases cell membrane glycoproteins like, presepsin (P-SEP), soluble urokinase plasminogen activator receptor (suPAR) and soluble triggering receptor expressed on myeloid cell 1 (sTREM-1). As percentage of cases suffer from sepsis increases, all these soluble glycoproteins can be utilized effectively as new sepsis biomarker for diagnosis, risk stratification and prognosis in SARS-CoV-2 infection [24-26]. Currently used sepsis biomarkers like WBC count, CRP, lactate, IL-6 and procalcitonin shows no significant difference between mild and severe cases of SARS-CoV-2 [27]. CRP has low sensitivity and it is unable to differentiate between viral and bacterial sepsis [28, 29]. Sensitivity, specificity and reported cut off values of procalcitonin are also variables in sepsis condition [30, 31]. In this review, we present current information on P-SEP, suPAR and sTREM-1 and their utility for diagnosis, risk stratification and prognosis of SARS-CoV-2 cases.

\section{Materials and Methods}

\section{Strategy for Literature Search}

Published studies on P-SEP, suPAR and sTREM-1 in SARS-CoV-2 infection were search from March 2020 to April 2021. Databases like, PubMed, Web of Science, EMBASE, and CNKI were used. MeSH keywords in English language using combinations like, P-SEP AND COVID-19 OR P-SEP AND SARS-CoV-2 OR P-SEP AND CORONOVIRUS DISEASES 2019 OR P-SEP AND 2019-nCoV, suPAR AND COVID-19 OR suPAR AND SARS-CoV-2 OR suPAR AND CORONOVIRUS DISEASES 2019 OR suPAR AND 2019-nCoV, and sTREM1AND COVID-19 OR sTREM-1 AND SARS-CoV-2 OR sTREM-1 AND CORONOVIRUS DISEASES 2019 OR sTREM-1 AND 2019-nCoV were utilized.

\section{Extraction of Data}

First two authors searched articles independently by using above key words and final articles were chosen mutually by both authors. We have chosen research literatures which have evaluated the utility of P-SEP, SUPAR and sTREM-1 in SARS-CoV-2 infections. Following data were extracted from chosen articles: Author's name, place of study, serum level of P-SEP, suPAR and sTREM-1 in various groups of SARS-COv-2 infection, their cut off values and correlation with CRP, procalcitonin (PCT), and D-dimer, their utility as prognostic marker or predictor of severity, AUC to predict severity/mortality and sample size. Data was extracted by one author and other author rechecked the data for accuracy.

\section{Results and Discussion}

We primarily retrieved total fifteen research literature from different databases. Finally, we have selected total nine research literature after removing duplicates studies for this review to reach the conclusion. Figure 1 depicts the flow of process for selection of research literature according to the PRISMA guideline.

\section{Utility of P-SEP in SARS-CoV-2 Infection}

CD 14 is a glycoprotein and receptor for lipopolysaccharide-lipopolysaccharide binding protein (LPS-LBP) compound, expressed on cell surface of monocyte, dendritic cells and macrophage.

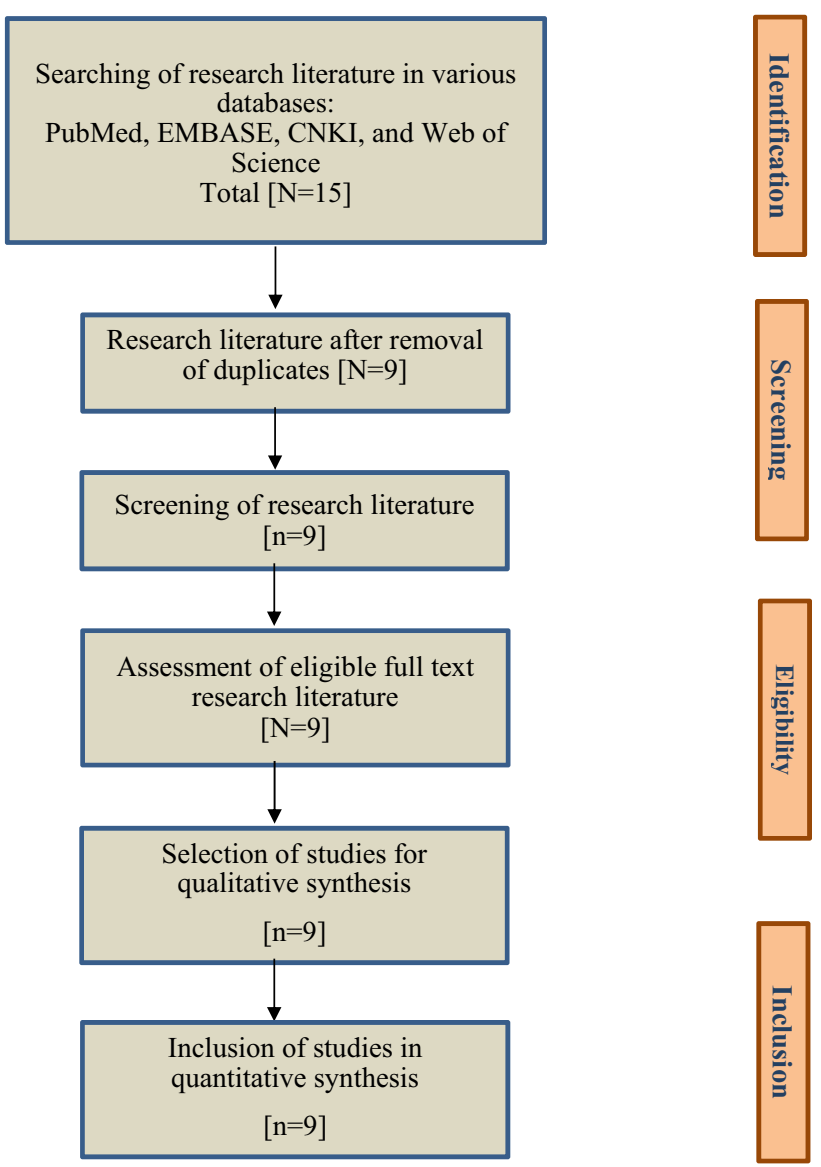

Fig. 1 Flow of process for selection of research literature according to the PRISMA guidelines 
It transfers endotoxin signal from bacteria through Toll like receptor-4 leads to activation of mitogen-activated protein kinase, tyrosine protein kinase and NF- $\kappa \mathrm{B}$ pathway, results in release of IFN- $\gamma$, TNF- $\alpha$, IL-1, IL-6 and IL8. Subsequently activation of fibrinolysis and coagulation pathway causes DIC, septic shock and multi organ injury $[32,33]$. After coming in contact with infectious pathogen, $13 \mathrm{kDa}$ amino (N) - terminal of CD 14 is cleaved and released into circulation. This soluble subtype of CD 14 is known as P-SEP [34, 35]. Precise role of P-SEP is still unknown, but it thought to be involved in lysosomal cleavage and phagocytosis of microbes. It may interact with $\mathrm{B}$ cells and $\mathrm{T}$ cells to regulate the immune response and also acts as a receptor for lipopolysaccharide which is present in cell walls of gram-negative bacteria [36, 37]. Elevated level of serum P-SEP has been reported in patients of sepsis, even before procalcitonin and IL-6 $[38,39]$. P-SEP can be measured only in 25 to 30 minutes by electrochemiluminescent enzyme assay [40] and can be used to diagnose sepsis in SARS-CoV-2 patients.

Several studies reported utility of P-SEP in SARS-CoV2 infection. Zaninottoa $\mathrm{M}$ et al. [41] have found a cut off value of $250.0 \mathrm{ng} / \mathrm{ml}$ for risk stratification of SARS-CoV-2 infection. Patients presenting with values $>250.0 \mathrm{ng} / \mathrm{L}$ did remain in ICU for a significantly longer time compared to lower values. P-SEP was significantly high in patients those who died due to SARS-CoV-2 (Median: 1046.0, IQR: 763.0-1240.0; vs. median: 417.0, IQR: 281.0-678.0 ng/L, $p<0.05)$. P-SEP level was significantly correlated with CRP, procalcitonin and LDH [41]. Schirinzi et al. [42] and Fukada et al. [43] have also reported significantly high level of P-SEP in severe type of cases compared to moderate and mild type of SARS-CoV-2 cases. P-SEP was elevated before the increase in Krebs von den Lungen 6 (KL-6), suggests better predictive marker to predict critical or ARDS cases [43]. Table 1 depicts Summary of data extracted for P-SEP in SARS-CoV-2 infection from various studies.

\section{Utility of STREM-1 in SARS-CoV-2 Infection}

Triggering receptor expressed on myeloid cell-1 (TREM-1) is highly expressed on surface of monocyte, macrophage and neutrophils and it is a component of immunoglobulin (Ig) superfamily. It modulates immune response by increasing or decreasing the signal of Toll like receptor (TLR) [44, 45]. Activation of TLR-4 receptor stimulates TREM-1 and it cleaves into soluble TREM-1 by metalloproteinase. sTREM-1 is a soluble form of TREM-1 and it also expressed on monocyte and neutrophils. It also activates inflammatory response in presence of bacteraemia through TLR signal and releases proinflammatory mediators like IL-1 $\beta$ and TNF- $\alpha$. into circulation [46, 47]. Several studies have reported STREM-1 role in diagnosis and prognosis of sepsis and systemic inflammation [26, 48-50], but its exact role in SARS-CoV-2 has not been explored. It has been suggested that TREM- signalling pathway of macrophage or monocyte might also involve in

Table 1 Summary of data extracted for P-SEP in SARS-COv-2 infection from various studies

\begin{tabular}{|c|c|c|c|}
\hline \multirow[b]{2}{*}{ Author } & \multicolumn{3}{|l|}{ P-SEP in SARS-CoV-2 infection } \\
\hline & Zanninotto $\mathrm{M}$ et al. [41] & $\begin{array}{l}\text { Schirinzi A et al. } \\
\text { [42] }\end{array}$ & Fukada A et al.[43] \\
\hline Place of study & Padova, Italy & Bari, Italy & Saitama, Japan \\
\hline Sample size & 75 & 134 & 06 \\
\hline $\begin{array}{l}\text { Serum level in moderate to severe type of } \\
\text { SARS-CoV-2 infection }\end{array}$ & High & High & High \\
\hline $\begin{array}{l}\text { Critical cases vs. Mild / Moderate cases [ng/L } \\
\text { Median (Range) or Mean] }\end{array}$ & $\begin{array}{l}1069.0(695.0-2299.0) \text { vs. } 408.0 \\
\quad(202.0-660.0) p<0.05\end{array}$ & $\begin{array}{c}3024.0 \text { vs. } 737.0 \\
p<0.0001\end{array}$ & Not mentioned \\
\hline $\begin{array}{l}\text { Dead vs. discharged [ng/L median (Range) or } \\
\text { Mean] }\end{array}$ & $\begin{array}{l}1046.0(763.0-1240.0) \text { vs. } 417.0 \\
\quad(281.0-678.0) p<0.001\end{array}$ & $\begin{array}{l}2543.0 \text { vs. } 727.0 \\
p<0.0001\end{array}$ & $\begin{array}{l}626.0(314.0-784.0) \text { vs } 307.0 \\
\quad(198.0-352.0) p<0.05\end{array}$ \\
\hline Cut off value & $>250.0 \mathrm{ng} / \mathrm{L}$ & $>1179.0 \mathrm{ng} / \mathrm{L}$ & Not mentioned \\
\hline AUC for predicting mortality or severity & 0.72 & 0.73 & Not mentioned \\
\hline Correlation with $\mathrm{CRP} /$ procalcitonin & Positive correlation & $\begin{array}{l}\text { Positive } \\
\text { correlation }\end{array}$ & Positive correlation \\
\hline $\begin{array}{l}\text { Able to identify high risk patients and to } \\
\text { hospital stay }\end{array}$ & Yes & Not mentioned & Yes \\
\hline Limitation & $\begin{array}{l}\text { Non-availability of sample at admission } \\
\text { and limited sample size }\end{array}$ & Not mentioned & Limited sample size \\
\hline
\end{tabular}


Table 2 Summary of data extracted for suPAR in SARS-COv-2 infection from various studies

\begin{tabular}{|c|c|c|c|c|c|}
\hline \multirow[b]{2}{*}{ Author } & \multicolumn{5}{|c|}{ suPAR in SARS-CoV-2 infection } \\
\hline & Rovina N et al. [63] & Huang M et al. [64] & $\begin{array}{l}\text { Kyriazopoul-ou E } \\
\text { et al. [65] }\end{array}$ & $\begin{array}{l}\text { Azam TQ } \\
\text { et al. [66] }\end{array}$ & $\begin{array}{l}\text { Chalkias A } \\
\text { et al. [67] }\end{array}$ \\
\hline Place of study & Chicago, USA & Fuijan, China & Athens, Greece & $\begin{array}{l}\text { Ann Arber, } \\
\text { MI }\end{array}$ & Larisa, Greece \\
\hline Sample size & 57 & 117 & 130 & 352 & Not mentioned \\
\hline $\begin{array}{l}\text { Serum level in severe/critical type of } \\
\text { SARS-CoV-2 infection }\end{array}$ & $\begin{array}{l}\text { Increased }>6.0 \mathrm{ng} / \\
\mathrm{ml}\end{array}$ & $\begin{array}{l}\text { Increased } \\
5.51 \pm 2.53 \mathrm{ng} / \\
\mathrm{ml}\end{array}$ & $\begin{array}{l}\text { Increased }>6.0 \mathrm{ng} / \\
\mathrm{ml}\end{array}$ & $\begin{array}{l}\text { Increased } \\
5.61 \mathrm{ng} / \mathrm{ml}\end{array}$ & Increased \\
\hline $\begin{array}{l}\text { Correlation with Severity/Respiratory } \\
\text { failure/ Mortality }\end{array}$ & Positive correlation & Positive correlation & Positive correlation & $\begin{array}{l}\text { Positive } \\
\text { correlation }\end{array}$ & $\begin{array}{l}\text { Positive } \\
\text { correlation }\end{array}$ \\
\hline Correlation with CRP/D-Dimer/PCT & Positive correlation & Positive correlation & Positive correlation & $\begin{array}{l}\text { Positive } \\
\text { correlation }\end{array}$ & No correlation \\
\hline $\begin{array}{l}\text { Increased in progressive kidney } \\
\text { dysfunction }\end{array}$ & Yes & Not mentioned & Not mentioned & Yes & Not mentioned \\
\hline $\begin{array}{l}\text { Sensitivity for predicting respiratory } \\
\text { failure/Mortality }\end{array}$ & $85.7 \%$ & $85.9 \%$ & Not mentioned & $\begin{array}{l}\text { Not } \\
\text { mentioned }\end{array}$ & $>80 \%$ \\
\hline
\end{tabular}

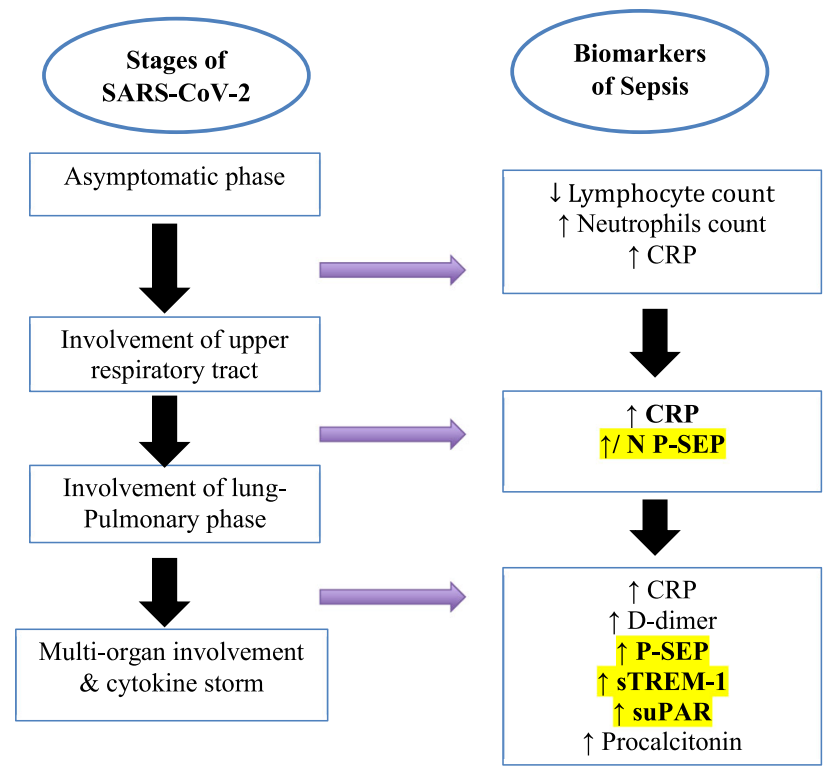

Fig. 2 Biomarkers of sepsis in different stages of SARS-CoV-2 infection

development of cytokine storm in SARS-CoV-2 infections [51]. Van Singer et al. [52] have reported significantly high value of sTREM-1 in severe type of SARS-CoV-2 cases and it had best prognostic accuracy with AUC of 0.86 at cut off of $689.0 \mathrm{pg} / \mathrm{mL}$ to predict 30-day mortality or intubation. sTREM-1 had a sensitivity of $94 \%$ to predict 30 days mortality when it used along with respiratory ratebased algorithm. sTREM-1 can be measured on automated platform by sandwich immunoassay based on monoclonal antibodies along with chemistry of streptavidin-biotin conjugate [52]

\section{Utility of SUPAR in SARS-CoV-2 Infection}

uPAR (urokinase-type plasminogen activator receptor) is an epithelial membrane bound GPI linked receptor of urokinase type plasminogen activator. UPAR cleaves into soluble form, suPAR during course of inflammation [53-56]. suPAR is expressed on endothelial cells, monocyte, neutrophils, macrophages and lymphocytes. It circulates in three forms- suPAR DI, suPAR DI-III and suPAR DII-III. The most active form is suPAR DI-III as it has high capability to bind with uPAR. It plays important role in various immunological functions like cell adhesion, cell proliferation, cell migration, angiogenesis and fibrinolysis process [57-59]. In endothelial cell, uPAR differentiates the signalling of uncleaved and cleaved form of kinogen. uPAR interacts with early complex kinogen in epithelial cell and may cause endothelial dysfunction in early stage of SARS-CoV-2. Persistent dysregulation of uPAR system in systemic inflammatory condition has been considered a main reason for morbidity and mortality. Thus, systemic inflammatory response and endothelial dysfunction in SARS-CoV-2 may be responsible for activation of uPAR system and results in pneumonia or ARDS [60]. Level of suPAR has been correlated with severity and mortality of SARS-CoV-2. In addition, uPAR system has been projected as a therapeutic target to diminish the mortality in SARS-CoV-2 [61]. Early increase in suPAR level also predicts 28-days outcome in patients of sepsis [62]. Hence, it is important to evaluate suPAR level in SARS-CoV-2 for early identification of high risks patients which require early admission and aggressive treatment. 
Rovina et al. have reported significantly high level of suPAR in SARS-CoV-2 who have developed systemic respiratory failure. suPAR was significantly high in 30-days non-survival group $(6.7-11.8 \mathrm{ng} / \mathrm{ml})$ compared to 30-days survival group $(2.6-4.7 \mathrm{ng} / \mathrm{ml})$ in emergency department. They reported a cut off value of $\geq 6.0 \mathrm{ng} / \mathrm{ml}$ for development of respiratory failure with sensitivity and specificity of $85.1 \%$ and $91.7 \%$. Time for development of respiratory failure was very short in patients having suPAR of $\geq 6.0 \mathrm{ng} / \mathrm{ml}$ [63]. Huang et al.*** have reported high level of active suPAR in SARS-CoV-2 patients $(5.51 \pm$ $2.53 \mathrm{ng} / \mathrm{mL})$ compared to healthy controls $(1.97 \pm 0.78 \mathrm{ng} /$ $\mathrm{mL}$ ). They also reported that suPAR level was positively correlated with severity of SARS-CoV-2 [64]. Kyriazopoulou et al. [65] have also reported high level of suPAR in SARS-CoV-2 infection and developed early suPAR directed anakinra treatment for management of respiratory failure. Azam et al. [66] have found median suPAR value of $5.61 \mathrm{ng} / \mathrm{ml}$ and suPAR can be used to predict acute kidney injury in SARS-CoV-2 infection. Chalkias et al. [67] have found elevated level of suPAR and concluded that suPAR can be utilized as triage biomarker for predicting admission in critical care and complication of SARS-CoV-2 infection. suPAR can be measured on automated platform by enzyme immunoassay, turbidimetric assay, and lateral flow immunoassay quick test which use two types of monoclonal antibodies [64]. Table 2 depicts Summary of data extracted for suPAR in SARS-COv-2 infection from various studies.

Figure 2 depicts trends of rising of various biomarker of sepsis in different stages of SARS-CoV-2. P-SEP may elevate at early stage in course of SARS-CoV-2. P-SEP, sTREM-1 and suPAR may be used as sepsis biomarker along with CRP for better identification of severe cases which require hospitalization and aggressive treatment.

\section{Limitation and Future Perspectives}

Lack of availability of more studies, heterogenicity of studies, smaller sample size, and different devices for analysis are some limitations of this review. In patients of SARS-CoV-2 infection, biomarkers such as P-SEP, sTREM-1, and suPAR biomarkers can be analysed promptly and easily in plasma or serum sample. These accessible biomarkers allow clinicians to receive a prompt prognosis because the results can be received prior to hospital admission, at bed site in intensive care unit and in other hospital settings. P-SEP, sTREM-1, and suPAR could be a potential target for rapid triage test and biomarkers to predicts clinical severity, mortality and 30-days readmission during COVID-19 pandemic.

\section{Conclusion}

P-SEP, sTREM-1 and suPAR might be potential sepsis biomarkers for SARS-CoV-2 pneumonia and they help to identify the high-risk patients at the earliest, so adverse outcome should be reduced by close monitoring and aggressive treatment strategies.

\section{Funding None.}

\section{Declarations}

Conflict of interest The authors declare that they have no conflicts of interest.

\section{References}

1. Mitra P, Misra S, Sharma P. One year of COVID-19: The "New Normal". Ind J Clin Biochem 2021.

2. Sohrabi C, Alsafi Z, O'Neill N, Khan M, Kerwan A, Al-Jabir A, et al. World Health Organization declares global emergency: a review of the 2019 novel coronavirus (COVID-19). Int J Surg. 2020;76:71-6.

3. Cucinotta D, Vanelli M. WHO Declares COVID-19 a Pandemic. Acta Biomed. 2020;91:157-60.

4. WHO Coronavirus Disease (COVID-19) Dashboard n.d. https:// covid19. who.int. Accessed 14 June 2021.

5. Karia R, Gupta I, Khandait H, Yadav A, Yadav A. COVID-19 and its modes of transmission. SN Compr Clin Med. 2020;1:1-4.

6. Sanyaolu A, Okorie C, Marinkovic A, Patidar R, Younis K, Desai P, Hosein Z, Padda I, Mangat J, Altaf M. Comorbidity and its impact on patients with COVID-19. SN Compr Clin Med. 2020;25:1-8

7. Rosenthal N, Cao Z, Gundrum J, Sianis J, Safo S. Risk Factors Associated With In-Hospital Mortality in a US National Sample of Patients With COVID-19. JAMA Netw Open. 2020;3:e2029058.

8. Kakodkar P, Kaka N, Baig MN. A comprehensive literature review on the clinical presentation, and management of the pandemic coronavirus disease 2019 (COVID-19). Cureus. 2020;12:e7560.

9. Diorio C, Henrickson SE, Vella LA, McNerney KO, Chase J, Burudpakdee $\mathrm{C}$, et al. Multisystem inflammatory syndrome in children and COVID-19 are distinct presentations of SARS-CoV2. J Clin Invest. 2020;130:5967-75.

10. Payne S. Family Coronaviridae. Viruses. 2017;149-58.

11. Li F. Structure, function, and evolution of coronavirus spike proteins. Annu Rev Virol. 2016;3:237-61.

12. Benton DJ, Wrobel AG, Xu P, Roustan C, Martin SR, Rosenthal $\mathrm{PB}$, et al. Receptor binding and priming of the spike protein of SARS-CoV-2 for membrane fusion. Nature. 2020;588:327-30.

13. Jaimes JA, Millet JK, Whittaker GR. Proteolytic Cleavage of the SARS-CoV-2 Spike Protein and the Role of the Novel S1/S2 Site. iScience. 2020;23:101212.

14. Walls AC, Park YJ, Tortorici MA, Wall A, McGuire AT, Veesler D. Structure, function, and antigenicity of the SARS-CoV-2 spike glycoprotein. Cell. 2020;181:281-292.e6.

15. Cascarina SM, Ross ED. A proposed role for the SARS-CoV-2 nucleocapsid protein in the formation and regulation of biomolecular condensates. FASEB J. 2020;34:9832-42. 
16. Hartenian E, Nandakumar D, Lari A, Ly M, Tucker JM, Glaunsinger BA. The molecular virology of coronaviruses. J Biol Chem. 2020;295:12910-34.

17. Zheng J. SARS-CoV-2: an emerging coronavirus that causes a global threat. Int J Biol Sci. 2020;16:1678-85.

18. Libby P, Luscher T. COVID-19 is, in the end, an endothelial disease. Eur Heart J. 2020;41:3038-44.

19. Lin SH, Zhao YS, Zhou DX, Zhou FC, Xu F. Coronavirus disease 2019 (COVID-19): cytokine storms, hyper-inflammatory phenotypes, and acute respiratory distress syndrome. Genes Dis. 2020;7:520-7.

20. Cavezzi A, Troiani E, Corrao S. COVID-19: hemoglobin, iron, and hypoxia beyond inflammation. A narrative review Clin Pract. 2020;10:1271.

21. Yuki K, Fujiogi M, Koutsogiannaki S. COVID-19 pathophysiology: a review. Clin Immunol. 2020;215:108427.

22. Delano MJ, Ward PA. The immune system's role in sepsis progression, resolution, and long-term outcome. Immunol Rev. 2016;274:330-53.

23. Thomas-Ruddel D, Winning J, Dickmann P, Ouart D, Kortgen A, Janssens U, et al. Coronavirus disease 2019 (COVID-19): update for anesthesiologists and intensivists. Anaesthesist. 2020; 1-10

24. Wiersinga WJ, Leopold SJ, Cranendonk DR, van der Poll T. Host innate immune responses to sepsis. Virulence. 2014;5:36-44.

25. Aziz M, Jacob A, Yang WL, Matsuda A, Wang P. Current trends in inflammatory and immunomodulatory mediators in sepsis. J Leukoc Biol. 2013;93:329-42.

26. Larsen FF, Petersen JA. Novel biomarkers for sepsis: a narrative review. Eur J Intern Med. 2017;45:46-50.

27. Kermali M, Khalsa RK, Pillai K, Ismail Z, Harky A. The role of biomarkers in diagnosis of COVID-19 - A systematic review. Life Sci. 2020;254:117788.

28. Markanday A. Acute Phase Reactants in Infections: EvidenceBased Review and a Guide for Clinicians. Open Forum Infect Dis. 2015;2:ofv098

29. Standage SW, Wong HR. Biomarkers for pediatric sepsis and septic shock. Expert Rev Anti-Infect Ther. 2011;9:71-9.

30. Liesenfeld O, Lehman L, Hunfeld KP, Kost G. Molecular diagnosis of sepsis: new aspects and recent developments. Eur $\mathrm{J}$ Microbiol Immunol. 2014;4:1-25.

31. Van Rossum AM, Wulkan RW, Oudesluys-Murphy AM. Procalcitonin as an early marker of infection in neonates and children. Lancet Infect Dis. 2004;4:620-30.

32. Tsukamoto H, Takeuchi S, Kubota K, Kobayashi Y, Kozakai S, Ukai I, et al. Lipopolysaccharide (LPS)-binding protein stimulates CD14-dependent Toll-like receptor 4 internalization and LPS-induced TBK1-IKKE-IRF3 axis activation. J Biol Chem. 2018;293:10186-201.

33. Mazgaeen L, Gurung P. Recent advances in lipopolysaccharide recognition systems. Int J Mol Sci. 2020;21:379.

34. Zou Q, Wen W, Zhang XC. Presepsin as a novel sepsis biomarker. World J Emerg Med. 2014;5:16-9.

35. Aliu-Bejta A, Atelj A, Kurshumliu M, Dreshaj S, Barsic B. Presepsin values as markers of severity of sepsis. Int J Infect Dis. 2020;95:1-7.

36. Chenevier-Gobeaux C, Borderie D, Weiss N, Mallet-Coste T, Claessens YE. Presepsin (sCD14-ST), an innate immune response marker in sepsis. Clin Chim Acta. 2015;450:97-103.

37. Arai Y, Mizugishi K, Nonomura K, Naitoh K, Takaori-Kondo A, Yamashita K. Phagocytosis by human monocytes is required for the secretion of presepsin. J Infect Chemother. 2015;21:564-9.

38. Yang HS, Hur M, Yi A, Kim H, Lee S, Kim SN. Prognostic value of presepsin in adult patients with sepsis: Systematic review and meta-analysis. PLoS One. 2018;13:e0191486
39. Zhang X, Liu D, Liu YN, Wang R, Xie LX. The accuracy of presepsin (sCD14-ST) for the diagnosis of sepsis in adults: a meta-analysis. Crit Care. 2015;19:323.

40. Okamura Y, Yokoi H. Development of a point-of-care assay system for measurement of presepsin (sCD14-ST). Clin Chim Acta. 2011;412:2157-61.

41. Zaninotto M, Mion MM, Cosma C, Rinaldi D, Plebani M. Presepsin in risk stratification of SARS-CoV-2 patients. Clin Chim Acta. 2020;507:161-3.

42. Schirinzi A, Cazzolla AP, Lovero R, Lo Muzio L, Testa NF, Ciavarella D, et al. New insights in laboratory testing for COVID19 patients: looking for the role and predictive value of Human epididymis secretory protein 4 (HE4) and the innate immunity of the oral cavity and respiratory tract. Microorganisms. 2020;8:1718.

43. Fukada A, Kitagawa Y, Matsuoka M, Sakai J, Imai K, Tarumoto $\mathrm{N}$, et al. Presepsin as a predictive biomarker of severity in COVID-19: A case series. J Med Virol. 2020:https://doi.org/10. 1002/jmv.26164.

44. Tammaro A, Derive M, Gibot S, Leemans JC, Florquin S, Dessing MC. TREM-1 and its potential ligands in non-infectious diseases: from biology to clinical perspectives. Pharmacol Ther. 2017:177:81-95.

45. Dantas PHDS, Matos AO, da Silva FE, Silva-Sales M, SalesCampos H. Triggering receptor expressed on myeloid cells-1 (TREM-1) as a therapeutic target in infectious and noninfectious disease: a critical review. Int Rev Immunol. 2020;39:188-202.

46. Doughty C, O'Driscoll DN, Smith S, O'Currain E, Grant T, O'Hare FM, et al. Soluble triggering receptor expressed on myeloid cells-1 (sTREM-1) in neonatal sepsis. J Matern Fetal Neonatal Med. 2020;1-8

47. Lemarie J, Barraud D, Gibot S. Host response biomarkers in sepsis: overview on sTREM-1 detection. Methods Mol Biol. 2015; 1237:225-39.

48. Chen M, Zhu Y. Utility of sTREM-1 and Presepsin (sCD14-ST) as diagnostic and prognostic markers of sepsis. Clin Lab. 2020;66

49. Wu Y, Wang F, Fan X, Bao R, Bo L, Li J, et al. Accuracy of plasma sTREM-1 for sepsis diagnosis in systemic inflammatory patients: a systematic review and meta-analysis. Crit Care. 2012;16:R229.

50. Wright SW, Lovelace-Macon L, Hantrakun V, Rudd KE, Teparrukkul P, Kosamo S, et al. sTREM-1 predicts mortality in hospitalized patients with infection in a tropical, middle-income country. BMC Med. 2020;18:159.

51. Merad M, Martin JC. Pathological inflammation in patients with COVID-19: a key role for monocytes and macrophages. Nat Rev Immunol. 2020;20:355-62.

52. Van Singer M, Brahier T, Ngai M, Wright J, Weckman AM, Erice C, et al. COVID-19 risk stratification algorithms based on sTREM-1 and IL-6 in emergency department. J Allergy Clin Immunol. 2021;147:99-106.e4.

53. Mahmood N, Mihalcioiu C, Rabbani SA. Multifaceted role of the urokinase-type plasminogen activator (uPA) and its receptor (uPAR): diagnostic, prognostic, and therapeutic applications. Front Oncol. 2018;8:24.

54. Plesner T, Behrendt N, Ploug M. Structure, function and expression on blood and bone marrow cells of the urokinase-type plasminogen activator receptor, uPAR. Stem Cells. 1997; 15:398-408.

55. Stewart CE, Sayers I. Urokinase receptor orchestrates the plasminogen system in airway epithelial cell function. Lung. 2013;191:215-25.

56. Barinka C, Parry G, Callahan J, Shaw DE, Kuo A, Bdeir K, et al. Structural basis of interaction between urokinase-type plasminogen activator and its receptor. J Mol Biol. 2006;363:482-95. 
57. Genua M, D’Alessio S, Cibella J, Gandelli A, Sala E, Correale C, et al. The urokinase plasminogen activator receptor (uPAR) controls macrophage phagocytosis in intestinal inflammation. Gut. 2015;64:589-600.

58. Pliyev BK, Antonova OA, Menshikov M. Participation of the urokinase-type plasminogen activator receptor (uPAR) in neutrophil transendothelial migration. Mol Immunol. 2011;48:1168-77.

59. de Bock CE, Wang Y. Clinical significance of urokinase-type plasminogen activator receptor (uPAR) expression in cancer. Med Res Rev. 2004;24:13-39.

60. Schultz M, Rasmussen LJH, Hoi-Hansen T, Kjoller E, Jensen $\mathrm{BN}$, Lind $\mathrm{MN}$, et al. Early discharge from the emergency department based on soluble urokinase plasminogen activator receptor (suPAR) levels: a TRIAGE III substudy. Dis Markers. 2019;2019:3403549.

61. D'Alonzo D, De Fenza M, Pavone V. COVID-19 and pneumonia: a role for the uPA/uPAR system. Drug Discov Today. 2020;25:1528-34.

62. Giamarellos-Bourboulis EJ, Norrby-Teglund A, Mylona V, Savva A, Tsangaris I, Dimopoulou I, et al. Risk assessment in sepsis: a new prognostication score by APACHE II score and serum soluble urokinase plasminogen activator receptor. Crit Care. 2012;16:R149
63. Rovina N, Akinosoglou K, Eugen-Olsen J, Hayek S, Reiser J, Giamarellos-Bourboulis EJ. Soluble urokinase plasminogen activator receptor (suPAR) as an early predictor of severe respiratory failure in patients with COVID-19 pneumonia. Crit Care. 2020;24:187.

64. Huang M, Li L, Shen J, Wang Y, Wang R, Yuan C, et al. Plasma levels of the active form of suPAR are associated with COVID-19 severity. Crit Care. 2020;24:704.

65. Kyriazopoulou E, Panagopoulos P, Metallidis S, Dalekos GN, Poulakou G, Gatselis N, et al. An open label trial of anakinra to prevent respiratory failure in COVID-19. Elife. 2021;10:e66125.

66. Azam TU, Shadid HR, Blakely P, O'Hayer P, Berlin H, Pan M, et al. International study of inflammation in COVID-19. soluble urokinase receptor (SuPAR) in COVID-19-related AKI. J Am Soc Nephrol. 2020;31:2725-2735

67. Chalkias A, Mouzarou A, Samara E, Xanthos T, Ischaki E, Pantazopoulos I. Soluble urokinase plasminogen activator receptor: a biomarker for predicting complications and critical care admission of COVID-19 patients. Mol Diagn Ther. 2020;24:517-21.

Publisher's Note Springer Nature remains neutral with regard to jurisdictional claims in published maps and institutional affiliations. 